\title{
A Amoris Laetitia e sua fundamentação bíblica
}

Recebido: 29/05/2016. Aprovado: 10/06/2016.

\author{
Ney Brasil Pereira*
}

Resumo: O que se entende por "fundamentação bíblica" de um documento eclesiástico, no caso, da Exortação Apostólica "sobre a alegria do amor na família"? Obviamente, é a verificação da maneira como o autor do texto recorreu à Bíblia para justificar suas afirmações. Em outras palavras, qual a hermenêutica das citações bíblicas apresentadas pelo papa Francisco? Nesse sentido, meu trabalho não se reduzirá à mera identificação dos textos bíblicos em cada um dos nove capítulos. Além de identificá-los, procurarei contextualizá-los e, quando for o caso, avaliá-los do ponto de vista da exegese, contribuindo assim, espero, para uma melhor apreciação do documento. O desenvolvimento do trabalho percorrerá simplesmente a sequência dos nove capítulos, em cada um deles examinando as citações bíblicas explícitas, sem esquecer de aludir às citações implícitas.

Palavras-chave: Argumentação bíblica. Hermenêutica. Matrimônio. Família.

Abstract: What does one mean by "biblical foundation" of an ecclesiastical document, namely, of the Apostolic Exhortation "about joy of love in the family"? Obviously, it is the examination of the way how the author of the text resorted to the Bible in order to justify his assertions. In other words, which was the hermeneutics of the biblical quotations presented by pope Francis? In this way, the paper won't be reduced to the mere identification of the biblical texts in each one of the nine chapters. Besides identifying them, the author will try to show their context and, when necessary, will evaluate them from an exegetical point of view, so contributing to a better appreciation of the document. The paper will simply go through the sequence of the chapters, in each one examining the explicit biblical quotations, without forgetting to allude to the implicit quotations.

Key-words: Biblical argumentation. Hermeneutics. Marriage. Family.

* Mestre em Ciências Bíblicas, Pontifício Instituto Bíblico, Roma. Ex-membro da Pontifícia Comissão Bíblica. Professor Emérito da FACASC, Florianópolis, SC. 


\section{Introdução}

O que se entende por "fundamentação bíblica" de um documento eclesiástico, no caso, da Exortação Apostólica "sobre a alegria do amor na família"? Obviamente, é a verificação da maneira como o autor do texto recorreu à Bíblia para justificar suas afirmações. Em outras palavras, qual a hermenêutica das citações bíblicas apresentadas pelo papa Francisco? Nesse sentido, meu trabalho não se reduzirá à mera identificação dos textos bíblicos em cada um dos nove capítulos. Além de identificá-los, procurarei contextualizá-los e, quando for o caso, avaliá-los do ponto de vista da exegese, contribuindo assim, espero, para uma melhor apreciação do documento.

A propósito, chamou-me a atenção o destaque dado por Francisco, logo de início, ao texto de Jo $16,13^{1}$, o único citado na breve introdução ao documento. Aliás, o Papa não o cita literalmente, mas refere-se de modo enfático ao seu conteúdo. Com efeito, mesmo reconhecendo que é "necessária, na Igreja, uma unidade de doutrina e práxis, isto não impede que existam maneiras diferentes de interpretar alguns aspectos da doutrina, ou algumas consequências que dela decorrem. E assim há de acontecer até que o Espírito nos conduza à verdade completa (cf. Jo $16,13)^{2}$, isto é, quando nos introduzir perfeitamente no mistério do Cristo e pudermos ver tudo com seu olhar" (n. 3) ${ }^{3}$. Salta aos olhos a importância desta citação e, igualmente, a sua justificativa, para iluminar toda a nossa avaliação da "fundamentação bíblica" da Amoris Laetitia.

O desenvolvimento do trabalho percorrerá simplesmente a sequência dos nove capítulos, em cada um deles examinando as citações bíblicas explícitas, sem omitir uma referência às citações implícitas.

1 É a última das cinco promessas do Paráclito, feitas por Jesus nos capítulos 14-16 do quarto evangelho.

2 Assim, o texto da Nova Vulgata: “...deducet vos in omnem veritatem", indicando movimento. O texto original, gr., é discutido: alguns manuscritos leem hodêgêsei hymâs en tê alêtheia pásê, sem movimento, enquanto outros leem eis tên alêtheian pásan, opção preferida pela Nova Vulgata. A Bíblia da CNBB, na edição que tenho, segue a primeira forma do texto gr., e tem interessantes paralelos textuais em nota, p. ex. no SI 25,5: Faz-me caminhar na tua verdade...

3 As citações do documento serão indicadas apenas pelo número oficial, sem a sigla $\mathrm{AL}$, de Amoris Laetitia. E a edição brasileira que estou seguindo é a das Edições CNBB. 


\section{No capítulo I}

O capítulo primeiro, com o indicativo título "À luz da Palavra", é o que concentra as citações, começando com uma visão de conjunto: "A Bíblia aparece cheia de famílias, gerações, histórias de amor e crises familiares, desde as primeiras páginas... até as últimas..." (n. 8). Segue a referência às "duas casas" de que fala Jesus no final do sermão da Montanha, casas "construídas ora sobre a rocha ora sobre a areia" (Mt 7,24-27) ${ }^{4}$. A menção da casa leva Francisco a citar integralmente o salmo 128(127), "que ainda hoje se proclama nas liturgias nupciais quer judaicas, quer cristãs" (n. 8), e que parabeniza o esposo, feliz com a esposa e os filhos, realizando "o desígnio primordial que o próprio Cristo evoca com decisão: Nunca lestes que o Criador, desde o princípio, os fez homem e mulher? (Mt 19,4).

Sabemos o contexto em que Jesus faz esta evocação, quando provocado pelos fariseus sobre a questão do divórcio ${ }^{5}$, ocasião em que ele retoma o mandato do livro do Gênesis: Por isso, deixará o homem seu pai e sua mãe e se unirá à sua mulher, e eles serão uma só carne (Gn $2,24)$. A propósito dos dois primeiros capítulos do Gênesis, o papa os qualifica de "grandiosos", ao nos oferecerem "a representação do casal humano em sua realidade fundamental" (n. 10). Depois de comentar Gn 1,27 com a sua ousada apresentação da sexualidade humana ${ }^{6}$ como "imagem de Deus" e, também, o Crescei e multiplicai-vos, de Gn 1,287, Francisco escreve que "a capacidade que o casal humano tem de gerar é o caminho por onde se desenrola a história da salvação". E continua: "Sob esta luz, a relação fecunda do casal torna-se uma imagem para descobrir e descrever o mistério de Deus, fundamental na visão cristã da Trindade que, em Deus, contempla o Pai, o Filho e o Espírito de amor" (n. 11).

A seguir, Francisco destaca dois "detalhes elucidativos" no "retrato admirável" do casal humano em Gn 2: primeiro, a "inquietação vivida pelo homem, que busca uma auxiliar que lhe corresponda" (vv. 18.20), a qual, por intervenção do Senhor, vem a surgir de um dos seus lados (vv.21-22)

\footnotetext{
4 Também no final do sermão da Planície (Lc 6,47-49).

5 Mt 19,3-9, a comparar com seu paralelo Mc 10,2-9.

6 O texto original, nesse versículo, não fala em "homem e mulher", mas, literalmente, em macho e fêmea, hebr. zakar û neqebâ.

7 Segundo a tradição rabínica, é "o primeiro mandamento da Torá".

8 Não "de uma das costelas", tradução usual do hebr. tselá', que corresponde ao gr. pleurá, "lado", como se pode constatar em quatro incidências desse termo em Jo 19-
} 
segundo, "a geração e a família", resultante "desse encontro que cura a solidão", encontro expresso com a afirmação do v. 24, citada por Jesus: "ele se unirá à sua mulher, e serão os dois uma só carne" (Mt 19,5). Bela, a conclusão desse parágrafo: "O fruto dessa união é tornar-se uma só carne, quer no abraço físico, quer na união dos corações e das vidas e, porventura, no filho que nascerá dos dois e, em si mesmo, há de levar'9 as duas 'carnes', unindo-as genética e espiritualmente" (n. 13). Quanto aos filhos, retratados "como brotos de oliveira" no S1 128,3, e "como flechas nas mãos de um guerreiro", no Sl 127/126,4, Francisco observa que, mesmo sob imagens de uma cultura antiga, "a presença dos filhos é um sinal de plenitude da família na continuidade da mesma história de salvação" (n. 14).

Depois de apresentar a dimensão de "igreja doméstica, que encontramos no Novo Testamento (vários textos das cartas paulinas, no n. 15), Francisco lembra que a Bíblia considera a família "também como o local da catequese dos filhos", segundo o que se estabelece para a celebração da ceia pascal (cf. Ex 12,26-27) e, belamente, no S1 78/77,3-6. Se os pais "têm o dever de cumprir, com seriedade, a sua missão educativa", como ensinam várias passagens dos Provérbios, aos filhos compete o dever de "honrar pai e mãe" (Ex 20,12), primeiro dos mandamentos da segunda tábua do Decálogo.

No subtítulo "Um rastro de sofrimento e sangue" (n. 19), Francisco começa observando que "o idílio do salmo 128/127" não nega a realidade do mal que perpassa toda a Escritura. E é significativo que a palavra de Jesus sobre o matrimônio (Mt 19,3-9) apareça inserida numa disputa sobre o divórcio. Mais ainda, "desde os primórdios, com o pecado, a relação de amor e pureza entre o homem e a mulher se transformou em domínio: "Teus desejos ${ }^{10}$ te arrastarão para teu marido, e ele te dominará" (Gn 3,16). Segue-se uma impressionante síntese do "sofrimento e sangue" no Antigo Testamento, em poucas linhas (n. 20), bem como, um pouco mais detalhadamente, na maneira como o próprio Jesus viveu e conheceu "as ansiedades e tensões" da vida em família (n. 21). Dessa forma, "a Palavra de Deus" - conclui Francisco (n. 21) - "não se apresenta

20, sempre significando "lado". Naturalmente, Francisco não entra nessa discussão nem alude a ela. Cf. minha argumentação em PEREIRA, N.B., "Costela ou lado de Adão, em Gn 2,21-22? Um texto de S. João Crisóstomo", in "Encontros Teológicos", revista da FACASC, Florianópolis, n. 56 (2010/2), pp. 171-175.

9 "Levar"? ou "trazer"?

10 "Teus desejos": ou, melhor, no singular, "teu desejo", como no TM e na LXX, bem como na NV. 
como uma sequência de teses abstratas, mas como uma companheira de viagem [...] mostrando-nos a meta do caminho, quando Deus enxugar toda lágrima de nossos olhos" (cf. Ap 21,4).

Do ponto de partida do documento, o S1 128/127, Francisco recolhe também o tema do trabalho, atividade fundamental do ser humano, hoje infelizmente negada para tantos, que sofrem "o desemprego e a precariedade laboral", à semelhança dos operários da parábola de Mt 20,1-16 (n. 25). Mas temos ainda, como consequência da degeneração que o pecado introduz na sociedade e na natureza, a "desertificação do solo" (cf. Gn $3,17-19$ ), além dos "desequilíbrios econômicos e sociais, contra os quais se levantou abertamente a voz dos profetas" (n. 26).

Concluindo o capítulo $1^{\circ}$ da Exortação, Francisco ressalta o "sinal distintivo" dos discípulos de Jesus, o amor mútuo (cf. Jo 13,34-35), como "essencial na experiência cristã do matrimônio e da família" (nn. 2728). Pede, também, que a família não esqueça a ternura, característica de vários textos que nos apresentam o relacionamento entre Deus e seu povo "com traços de amor paterno e materno", como o Sl 131/130,2", Oseias 11,3-4 e Is 49,15 (n. 28). E aponta para cada família "o ícone da família de Nazaré, com o seu dia a dia feito de fadigas e até de pesadelos, como quando teve de sofrer a violência incompreensível de Herodes, experiência que ainda hoje se repete tragicamente em muitas famílias de refugiados descartados e indefesos". Como Maria, as famílias são exortadas [...] "a guardar e meditar no coração" todas estas coisas (Lc 2,19.51), a saber, "as maravilhas de Deus" (n. 30).

\section{Nos capítulos II e III}

O capítulo II, intitulado "A realidade e os desafios das famílias", constitui o que chamaríamos a etapa do "Ver", na metodologia pastoral costumeira. Francisco optou por começar sua Exortação com a iluminação bíblica, justamente intitulada “À luz da Palavra", que corresponderia

11 Neste salmo, praticamente todas as versões, nas várias línguas, traduzem o hebr. gamûl por "desmamado", quando o sentido deve ser "amamentado", "saciado", como aliás o texto de Francisco o explica, no n. 28. Já no começo da década de 50, VOGT, Ernesto, na sua tradução dos Salmos ("Os salmos", São Paulo, LEB, 1951) e, recentemente, STADELMANN, Luís ("Os salmos da Bíblia", São Paulo, Paulinas e Loyola, 2015), são as únicas exceções honrosas que conheço. Na edição da CNBB, o texto da Exortação traz equivocadamente "criança desmamada", enquanto na edição da Paulus está correto: "criança saciada". 
à etapa do "Julgar", deixando assim bem claro que toda a sua reflexão quer ter por fundamento a palavra de Deus, consignada na Bíblia ${ }^{12}$. Por isso mesmo, são bem poucas, neste e no capítulo seguinte, as citações explícitas. Assim, a primeira que encontramos, e apenas como texto de referência, é, no n. 46, Mt 25,35 (Eu estava com fome..., Eu estava com sede...Eu era migrante, e me recebestes em casa), ao tratar das migrações, especialmente da "migração forçada das famílias".

Mais citações e/ou referências encontramos no capítulo III, "O olhar fixo em Jesus: a vocação da família". O Papa começa com a posição positiva do Novo Testamento, "contrariamente aos que proibiam o matrimônio", a saber, os maniqueus, citando 1Tm 4,4: Toda criatura de Deus é boa, e não se deve rejeitar coisa alguma que se usa com ação de graças. Também a carta aos hebreus: "O matrimônio seja honrado por todos, e o leito conjugal, sem mancha" (Hb 13,4). Depois, citando os Padres sinodais, Francisco escreve que "a indissolubilidade do matrimônio (O que Deus uniu, o homem não separe: Mt 19, $\left.6^{13}\right)$ não se deve entender primariamente como 'jugo', mas como 'dom' ... [...] e como plenitude da revelação que recupera o projeto originário de Deus (cf. Mt 19, $8^{14}$ )". Quanto à metáfora do "jugo", vemo-la empregada por Pedro, no "concílio" de Jerusalém, assumindo a posição de Paulo contra os judaizantes: "Por que agora colocais Deus à prova, querendo impor aos discípulos um jugo que nem nossos pais, nem nós mesmos pudemos suportar? Ao contrário, é pela graça do Senhor Jesus que cremos ter sido salvos..." (At 15,10-11).

Continua o Papa, ainda citando os Padres sinodais: "O exemplo de Jesus é paradigmático para a Igreja [...]. Ele inaugurou sua vida pública com o sinal de Caná, realizado num banquete de núpcias (cf. Jo 2,1-11)[...]. Compartilhou momentos frequentes de amizade com a família de Lázaro e suas irmãs (cf. Lc 10,38 e Jo 11,5) e com a família de Pedro (cf. Mt 8,14). Ouviu o pranto dos pais pelos seus filhos, restituindo-os à vida (cf. Mc 5,41: a filha de Jairo; Lc 7,14-15: o filho da viúva de Naim), assim manifestando o verdadeiro significado da misericórdia [...]. Isto, especialmente nos encontros com a mulher samaritana (cf. Jo 4,7-30) e com a adúltera (cf. Jo 8,1-11), nos quais a

12 Cf. as próprias palavras do Papa, na Introdução: "No desenvolvimento do texto, começarei por uma abertura inspirada na Sagrada Escritura, que Ihe dê o tom adequado" (n. 6).

13 A mesma palavra do Senhor é encontrada no texto paralelo de Mc 10,9.

14 No texto editado pela CNBB encontra-se, a meu ver equivocada, a citação de Mt 19,3. 
noção do pecado "desaparece" ${ }^{15}$ diante do amor gratuito de Jesus" (n. 64). Segue, da lavra do próprio Papa, e sem citações de textos, bela síntese sobre "a encarnação do Verbo em uma família humana, em Nazaré", a qual "comove, com a sua novidade, a história do mundo, [...] mistério que tanto fascinou Francisco de Assis, Teresa do Menino Jesus e Charles de Foucauld, e do qual bebem também as famílias cristãs para renovar sua esperança e alegria" (n. 65).

Mais adiante, Francisco destaca que os Padres sinodais, "assumindo o ensinamento bíblico de que tudo foi criado por Cristo e para Cristo (cf. $\mathrm{Cl} 1,16)$, lembram que a ordem da redenção ilumina e completa a ordem da criação e, assim, o matrimônio natural só se compreende à luz do seu cumprimento sacramental" (n. 77). E da mesma forma, "o olhar de Cristo, cuja luz ilumina cada ser humano (cf. Jo 1,9), inspira o cuidado pastoral da Igreja pelos fieis que simplesmente convivem, ou que só contraíram o casamento civil, ou então que são divorciados recasados" (n. 78).

\section{No capítulo IV}

Neste capítulo, intitulado "O amor no matrimônio", Francisco propõe algumas características do amor verdadeiro, destacando-as do conhecido hino à caridade escrito por São Paulo, na primeira carta aos coríntios, versículos 4 a 7 do capítulo 13 . O que chama a atenção é a explicação exegética dos termos paulinos, a partir do texto grego original.

Assim, a primeira qualidade, a "paciência", característica do Deus da Aliança, que é "lento para a ira" (cf. Ex 34,6; Nm 14,18). O termo usado por Paulo é o verbo makrothymein, literalmente: ser longânime, não se deixar levar pelos impulsos, pela raiva, mas "atuar com misericórdia", saber conviver com o diferente, p. ex. na família (n. 91). Nesse sentido, bem lembrada a exortação de Ef 4,31: Desapareça do meio de vós todo amargor e exaltação, toda ira e gritaria, ultrajes e toda espécie de maldade.

Segunda qualidade, a "atitude de serviço", que Paulo exprime com o verbo chrêstéuomai, derivado de chrêstós $^{I 6}$ : bondoso, serviçal, prestativo, indicando que a "paciência", nomeada em primeiro lugar, não

15 No texto editado pela CNBB aparece aqui o verbo "desperta", de difícil compreensão no contexto. Daí a minha sugestão acima.

16 No texto, o "chi” do gr. está transliterado à moda espanhola, com "j”: "jrestéuomai", "jrestós", o que fica meio estranho para nós. 
é uma atitude meramente passiva (n. 93). Terceira qualidade, expressa com o verbo zêlóo, invejar, com a partícula negativa - "não invejar" leva a apreciar os sucessos alheios, descentrando-nos de nós mesmos, aceitando os dons diferentes dos outros (n. 95). Modelo dessa atitude é Barnabé, segundo os Atos dos Apóstolos $(11,22-24)$ : ao ver quanto bem a graça de Deus havia realizado em Antioquia, ele 'alegrou-se muito", ao invés de, como os judaizantes, sentir inveja dos progressos daquela igreja. Quarta qualidade, a humildade, descrita como a atitude de quem não é presunçoso, em gr. perperéuomai, "vangloriar-se", nem "se incha de orgulho", em gr. physioûmai, verbo que Paulo usa também na 1Cor 8,1, ao falar do "conhecimento que incha". E Francisco comenta: "A atitude de humildade aparece aqui como fazendo parte do amor, porque, para poder compreender, desculpar ou servir os outros de coração, é indispensável curar o orgulho e dispor-se a servir" (cf. n. 98).

Quinta qualidade, a delicadeza de quem não age de modo inconveniente ${ }^{17}$, em gr. aschêmonein ${ }^{18}$. No comentário, Francisco fala de "cortesia", "afabilidade", "atitude não invasiva", "capacidade de dizer palavras de incentivo", como as de Jesus: Coragem! Levanta-te! Vai em paz! Não tenhas medo! E conclui: "Não são palavras que humilham, angustiam, irritam, desprezam. Na família, é preciso aprender esta linguagem amável de Jesus" (n. 100). Sexta qualidade, o desprendimento, ou seja, o desinteresse pessoal, no sentido de antepor ao próprio interesse o do outro, como diz também a carta aos filipenses: Não cuide somente do que é seu, mas também do que é dos outros $(\mathrm{Fl} 2,4)$. A propósito, Francisco cita Tomás de Aquino: "É mais próprio da caridade querer amar do que querer ser amado" 19 (n. 101-102). Poderia aqui também ser lembrada a palavra de Jesus citada por Paulo, na sua despedida aos presbíteros de Éfeso: Há mais felicidade em dar do que em receber (At 20,35).

Sétima qualidade, o autocontrole diante da irritação. Paulo emprega o verbo paroksýnomai, irritar-se, de onde vem o substantivo "paroxismo", o auge de uma emoção. Comenta Francisco: "A indignação é saudável, quando nos leva a reagir perante uma grave injustiça; mas é prejudicial, quando tende a impregnar todas as nossas atitudes para com os outros" (n. 103). A propósito, lembra a recomendação de Paulo aos efésios: Podeis irar-vos, contanto que não pequeis. Não se ponha o sol sobre

\footnotetext{
17 Melhor do que "vergonhoso", como está na tradução da CNBB.

18 Novamente, no texto, a transliteração do "chi" à moda espanhola, com "j": asjemonein.

19 Summa Theologiae, II-II, q.27, art. 1, ad 2.
} 
vossa ira $(\mathrm{Ef} 4,26)$. Por isso, "nunca se deve terminar o dia sem fazer as pazes na família" (n. 104). Oitava qualidade, a disposição de perdoar, não levando em conta o mal sofrido, em gr. ou logízetai to kakón. É a atitude positiva de compreender a fraqueza alheia e encontrar desculpas para a outra pessoa, não deixando que o ressentimento vá crescendo e crie raízes. Daí depende - e não é fácil! - a comunhão familiar, que "só pode ser conservada e aperfeiçoada com grande espírito de sacrifício, [...] com uma pronta e generosa disponibilidade à compreensão, à tolerância, ao perdão, à reconciliação" (n. 106).

Nona qualidade, a da verdadeira alegria: a de quem não se alegra com a injustiça, mas rejubila com a verdade, em gr.: ou cháirei epì tê adikía, sugcháirei dè tê alêthéia. ${ }^{20} \mathrm{E}$ a atitude de quem, longe de alegrarse com o fracasso, a injustiça sofrida pelo outro, alegra-se com o seu sucesso, com o reconhecimento de suas capacidades.

E o Papa comenta: "A família deve ser sempre o lugar em que uma pessoa que conquista algo de bom, sabe que com ela os seus vão se alegrar" (n. 110).

As quatro últimas qualidades são marcadas pela totalidade: "tudo", em gr. pánta.

Assim, diz Francisco, "destaca-se vigorosamente o dinamismo contracorrente do amor, capaz de enfrentar qualquer coisa que possa ameaçálo" (n. 111). Primeiro, "tudo desculpa", gr. pánta stégei, literalmente, tudo "encobre", no sentido de não difamar, não comentar os defeitos ou malfeitos do próximo. Em família, "o amor convive com a imperfeição, desculpa-a e sabe guardar silêncio - o que não quer dizer fechar-se ao diálogo! - perante os limites do ser amado" (n. 112). Segundo, "tudo crê", gr. pánta pistéuei, literalmente, tudo "acredita", não de modo ingênuo, mas no sentido de que "o amor confia, deixa em liberdade, renuncia a controlar tudo, a possuir, a dominar" (n. 115). Terceiro, "tudo espera”, gr. pánta elpizei, isto é, "sempre espera que seja possível um amadurecimento, um inesperado surto de beleza, que as potencialidades mais recônditas do ser germinem algum dia". De fato, é a esperança que nos faz contemplar o cônjuge com um olhar sobrenatural, aguardando a plenitude que virá (cf. n. 117). Quarto, "tudo suporta", gr. pánta hypoménei, não apenas tolerando, mas resistindo dinamicamente às contrariedades. Esta qualidade "manifesta uma dose de

20 De novo, na transliteração do gr., o "chi" de cháirei e de sygcháirei vem grafado à la espanhola, com "j". 
heroísmo tenaz, de força contra qualquer corrente negativa, uma opção pelo bem que nada pode derrubar" (p.118). Prossegue Francisco, depois de longa citação de Martin Luther King: "Na vida familiar, é preciso cultivar esta força do amor, que permite lugar contra o mal que a ameaça, [...] o amor que, apesar de tudo, não desiste" (n. 119).

Passando a comentar a "abertura ao definitivo", que marca a união conjugal, o Papa cita um texto de Malaquias, profeta pós-exílico, que denuncia adultério e divórcio: Porque o Senhor é testemunha entre ti e a mulher da tua juventude, a quem traiste. É ela a tua companheira, a esposa com a qual tens compromisso (M1 2,14) ${ }^{21}$. E comenta: "Para que este amor possa passar por todas as provações e manter-se fiel contra tudo, requer-se o dom da graça - sacramental - que o fortalece e eleva" (n. 124).

A seguir, ilustrando a partilha das alegrias da vida conjugal, cita breve conselho do Sirácida: Dá e recebe, e alegra a ti mesmo (Eclo 14,16).

Quanto a "esta forma particular de amor, que é o matrimônio, chamado a um amadurecimento constante", Francisco lembra a palavra de Paulo aos tessalonicenses: O Senhor vos faça crescer abundantemente no amor de uns para com os outros (1Ts 3,12). E comenta: "O amor que não cresce, começa a correr perigo" (n. 134). Ainda da primeira carta aos tessalonicenses, sobre a dimensão erótica do casamento, o Papa ressalta a perícope 1Ts 4,3-8, destacando o v. 6: Neste assunto, ninguém oprima ou prejudique o seu irmão, e lembra o ensinamento também de Paulo sobre o acordo entre os cônjuges quanto à sexualidade: Não vos recuseis um ao outro, a não ser de comum acordo e por algum tempo... (1Cor 7,5). Quanto à afirmação de Efésios 5,22, o Papa adverte que é preciso evitar sua "interpretação inadequada", tomando fora do contexto a diretiva de que "as mulheres sejam submissas ${ }^{22}$ a seus maridos". É que o versículo anterior diz, primeiro: Sede submissos uns aos outros, no temor de Cristo (Ef 5,21), isto é, a "submissão", o respeito, deve ser mútuo. Portanto, logicamente, também do marido à esposa. E o v. 25 adverte: Maridos, amai vossas mulheres, como também Cristo amou a Igreja... Por isso, escreve Francisco: "Esta recíproca ‘submissão', entre os cônjuges, adquire

21 Infelizmente, o texto original, hebr., tem lacunas, sendo de tradução conjectural. 0 verbo inicial do v.16 de Malaquias, aqui, é "Vigial", no imperativo, e não "Vigiais", como saiu no texto.

22 No texto original, o particípio "submissos", gr. hypotassómenoi, não está explícito no v. 22, como o supõem as traduções correntes, embora esteja implícito. A tradução exata deve ser: "As mulheres, aos seus maridos". 
um significado especial, devendo-se entender como uma pertença mútua livremente escolhida, com um conjunto de características de fidelidade, respeito e solicitude" (n. 156).

A seguir, refletindo sobre a virgindade, o Papa comenta os textos de Paulo na primeira carta aos coríntios (7,6-8.25,29-30.32), e cita João Paulo II: "Não se trata de diminuir o valor do matrimônio em favor da continência" (n. 159-160). Sobre o celibato, escreve que "corre o risco de ser uma cômoda solidão, que dá liberdade para se mover autonomamente, mudar de local, tarefa e opção, dispor do próprio dinheiro, conviver com as mais variadas pessoas... Neste caso, sobressai o testemunho das pessoas casadas [...] cuja capacidade de serviço oblativo e carinhoso [...] se torna, para as pessoas celibatárias, um convite a viverem a sua dedicação ao Reino com maior generosidade e disponibilidade" (n. 162).

\section{No capítulo $\mathrm{V}$}

Intitulado "O amor que se torna fecundo", neste capítulo Francisco trata dos filhos, "reflexo vivo do amor dos esposos, sinal permanente da unidade conjugal e síntese viva e indissociável do ser pai e mãe" ${ }^{23}$. Cada nova vida, escreve, "permite-nos descobrir a dimensão mais gratuita do amor, que nunca cessa de nos surpreender. É a beleza de ser amado primeiro: os filhos são amados antes de chegarem" (n. 166). Quanto às mães, elas são lembradas em vários textos bíblicos, p.ex. o S1 139-138,13: Tu me teceste no seio de minha mãe. Também na vocação de Jeremias: Antes de formar-te no seio de tua mãe, eu já te conhecia; antes de saíres do ventre, eu te consagrei $(\mathrm{Jr} 1,5)$.

O cântico de Maria, grávida de três meses (Lc 1,46-48), deveria inspirar a alegria de cada mãe, a quem Francisco pede que guarde a sua alegria de mãe, para poder transmiti-la ao filho (n. 171). Quanto aos que adotam uma criança, o Papa os vê como mediadores do amor de Deus, que diz, através do profeta: Ainda que tua mãe chegasse a esquecer-te, Eu nunca te esqueceria (Is 49,15). E as "famílias magnânimas e solidárias, que abrem espaço aos pobres", são as que cumprem as palavras de Jesus, em Mt 25,40: Todas as vezes que fizestes isso a um destes mais pequenos, que são meus irmãos, foi a mim que o fizestes. São também as que convidam os aleijados, os coxos, os cegos, à sua mesa (cf. Lc 14,12-14), e então serão felizes!

23 JOÃO PAULO II, Familiaris Consortio, n. 14. 
Com o subtítulo "Distinguir o Corpo", Francisco chama a atenção para o sentido "marcadamente social" da passagem da primeira Carta aos coríntios (11,17-34) $)^{24}$, na qual Paulo censura aquela comunidade por estar celebrando a Eucaristia sem se dar conta de que a estava "profanando". Por quê? Por desprezar os irmãos mais pobres. A profanação não era, portanto, por violação de alguma norma litúrgica ou por alguma situação de pecado pessoal, mas pelo desprezo/descuido dos pobres (n. 185-186). E hoje, as nossas Eucaristias?

O quarto mandamento, de Ex 20,12, honrar pai e mãe, inclui o dever de prover ao seu sustento e não abandoná-los, como Jesus recordou aos fariseus em Mc 7,8-1325.

"Mas há também a outra face da moeda", alerta o Papa, citando Gn 2,24: deixará o homem o pai e a mãe. E continua: "Às vezes, isto não é cumprido, nunca se chegando a assumir o matrimônio, porque falta esta renúncia e esta dedicação. [...] O matrimônio desafia a encontrar uma nova maneira de ser filho" (n. 190). Quanto aos idosos, Francisco cita uma das propostas do Sínodo de 2015: "Assim como Deus nos convida a sermos seus instrumentos para escutar a súplica dos pobres, assim também espera que ouçamos o brado dos idosos", como o que ouvimos no Sl 71/70,9. E continua: "Em uma civilização em que não há espaço para os idosos, ou onde eles são descartados porque criam problemas, tal sociedade traz em si o vírus da morte, pois se separa de suas próprias raízes" (n. 193).

\section{No capítulo VI}

Apresentando "algumas perspectivas pastorais", Francisco cita a parábola do semeador (Mt 13,3-9), à cuja luz percebemos, escreve ele, que "a nossa tarefa consiste em cuidar da semeadura: o resto é obra de Deus" (n. 200). Desta semeadura faz parte essencial o chamado "Evangelho da Família", que responde "às expectativas mais profundas da pessoa humana: a sua dignidade e plena realização na reciprocidade, na comunhão e na fecundidade" (n. 201). Comentando adiante o "acompanhamento nos primeiros anos da vida matrimonial", o Papa, falando do "amor artesanal", inspira-se na exclamação do homem diante da mulher, em Gn 2,23, e no que deve ter sido o "estupendo diálogo no qual o homem e a mulher fazem a

24 Cf. PEREIRA, Ney Brasil, "Paulo e a Eucaristia" (1Cor 11,17-34), in "Encontros Teológicos", revista do ITESC, Florianópolis, n. 44 (2006/2), pp. 163-167.

25 Cf. texto paralelo em Mt 15,4-6. 
mútua descoberta" (n. 221). A seguir, tratando da paternidade-maternidade responsável, e da formação da reta consciência, Francisco refere-se a Rm 2,15: Por sua maneira de proceder, mostram que a Lei está inscrita em seus corações. Disso dão testemunho igualmente sua consciência e os juizos éticos de acusação ou de defesa que fazem uns aos outros.

Sobre a convivência com o cônjuge não crente, assunto tratado por Paulo aos coríntios (1Cor 7,14), assim escreve o Papa: “Amar o cônjuge não crente, fazê-lo feliz, aliviar seus sofrimentos e partilhar a vida com ele, é um verdadeiro caminho de santificação" (n. 228). Mais adiante, ao refletir sobre o desafio que, na família, representa a morte de um ente querido, Francisco lembra a compaixão de Jesus no velório de Lázaro (Jo 11,33.35), e recomenda insistentemente que se acompanhe o luto pelos falecidos, iluminando a dor com as palavras da fé. "É verdade que a morte é algo de poderoso, mas o amor é forte como a morte $(\mathrm{Ct} 8,6)$. $\mathrm{O}$ amor possui uma intuição que lhe permite escutar sem sons e ver no invisível. Isto não é imaginar o ente querido como era, mas aceitá-lo transformado, como é agora" (n. 255). É o que Jesus ressuscitado fez ver a Maria Madalena, ao falar-lhe de um encontro diferente (cf. Jo 20,1726).

A seguir, iluminando a fé na outra vida daqueles que nos precederam, o Papa propõe-nos alguns textos. Assim, do livro da Sabedoria: Aos olhos dos insensatos, parecem ter morrido, [...] mas eles estão na paz (Sb 3,2-3). De Paulo, aos filipenses: Desejo ardentemente partir, para estar com Cristo (F1 1,23). Ainda Paulo, aos coríntios, falando da surpresa inaudita que Deus preparou para aqueles que O amam (1Cor $2,9)$. Sobre a oração pelos mortos, o autor do segundo livro dos Macabeus a apresenta como costume "santo e piedoso" (2Mc 14,45). Quanto à invocação dos mártires, no Apocalipse (6,9-11), não é propriamente uma "intercessão", mas um forte clamor para que Deus não tarde em fazer justiça (v.10). Por fim, a recomendação: "Se aceitarmos a morte, podemos preparar-nos para ela. O caminho é crescer no amor para com aqueles que, agora, caminham conosco, até o dia em que a morte não existirá mais (Ap 21,4). [...] E então reencontraremos os nossos entes queridos que morreram" (n. 258).

26 Cf. PEREIRA, Ney Brasil, "Não me toques, ou Não me busques? Uma nova tradução de Jo 20,17? Art. em "Encontros Teológicos", revista do ITESC, Florianópolis, n. 70 (2015/1), pp. 179-185. 


\section{No capítulo VII}

Tratando da educação dos filhos, "responsabilidade inevitável" dos pais, a ser assumida "de modo consciente, entusiasta, razoável e apropriado" (n. 259), o Papa lembra uma surpreendente recomendação da carta aos efésios: Vós, pais, não provoqueis revol$t a^{27}$ nos vossos filhos (Ef 6,4), cujo paralelo, com a sua motivação, temos na carta aos colossenses: Pais, não irriteis ${ }^{28}$ vossos filhos, para que eles não desanimem $(\mathrm{Cl} 3,21)$. E se pergunta: "Como fazer para que a disciplina seja limite construtivo do caminho que uma criança deve empreender e não um muro que a aniquile ou uma dimensão da educação que a iniba?” (n. 270).

Quanto à transmissão da fé, "dificultada pelo estilo de vida atual", é preciso "que os pais vivam a experiência real de confiar em Deus, de procurá-lo, de precisar dele, porque só assim uma geração contará à outra as obras de Deus e anunciará as suas maravilhas (cf. S1 145/144,4), e cada pai contará a seus filhos os gestos divinos do amor sempre fiel (cf. Is 38,19). Isto requer, continua Francisco, "que imploremos a ação de Deus nos corações, aonde não podemos chegar, certos de que o grão de mostarda (cf. Mt 13,31-32) vai tornar-se um grande arbusto" (cf. n. 287). Essa transmissão da fé não deve levar a família ao isolamento, mas ao testemunho missionário no meio do mundo, como o próprio Jesus (cf. várias passagens dos evangelhos, no n. 289). E Francisco conclui, citando a primeira carta de João: Nós, que cremos, reconhecemos o amor de Deus para conosco (1 Jo $4,16)$. "Só a partir desta experiência é que a pastoral familiar poderá conseguir que as famílias sejam simultaneamente igrejas domésticas e fermento evangelizador da sociedade" (n. 290).

\section{No capítulo VIII}

Este capítulo, bem "do jeito" de Francisco, propõe "acompanhar a fragilidade" dos casais em situação irregular, que no entanto continuam sendo filhos amados da Igreja. Trata-se de "acolhê-los e acompanhá-los com paciência e delicadeza" (n. 294), como Jesus fez com a Samaritana (cf. Jo 4,4-26). Mais adiante, Francisco faz uma alusão a Mt 18,17, ao

\footnotetext{
27 "Provocar revolta", em gr. parorgízete, exasperar, irritar, provocar ira, em gr. orgê.

28 "Irritar", em gr. erethízete, provocar, irritar.
} 
escrever: "Obviamente, se alguém ostenta um pecado objetivo como se fizesse parte do ideal cristão, ou quer impor algo diferente do que a Igreja ensina, não pode pretender dar catequese ou pregar e, neste sentido, há algo que o separa da comunidade. Precisa voltar a ouvir o anúncio do Evangelho e o convite à conversão" (n. 297).

Comentando "as normas e o discernimento", Francisco faz uma forte referência às invectivas de Jesus contra os "mestres da Lei", em Mt 23, sem citá-lo, ao escrever: "Um pastor não pode sentir-se satisfeito apenas aplicando leis morais aos que vivem em situações 'irregulares', como se fossem pedras que se atiram contra a vida das pessoas. É o caso dos corações fechados, que muitas vezes se escondem atrás dos ensinamentos da Igreja para se sentar na cátedra de Moisés e julgar, às vezes com superioridade e superficialidade, os casos difíceis e as famílias feridas" (n. 305). Finalmente, mesmo sem citar Mt 25,31-46, o Papa lembra que seremos julgados pelo amor, e que é o amor fraterno, a marca distintiva dos cristãos (cf. Jo 13,35), que nos salvará, como nos garante Pedro na sua primeira carta: Sobretudo, cultivai o amor mútuo, com todo o ardor, porque o amor cobre uma multidão de pecados (1Pd 4,8). Na mesma linha vai o conselho de Daniel a Nabucodonosor penitente: Paga teus pecados praticando a compaixão e repara tuas faltas cuidando dos pobres (Dn 4,24). Assim, "em toda e qualquer circunstância, perante quem tenha dificuldade em viver plenamente a lei de Deus, deve ressoar o convite a percorrer a via caritatis, o caminho do amor" (n. 306). Finalmente, aludindo a Mt 7,1 e Lc 6,37, Francisco nos lembra que "o próprio Evangelho exige que não julguemos nem condenemos" (n. 308).

\section{No capítulo IX}

Este último capítulo da Exortação é dedicado à "espiritualidade conjugal e familiar". Francisco nos surpreende com a beleza deste pensamento: "Sempre falamos da inabitação de Deus no coração da pessoa que vive na sua graça. Hoje podemos também dizer que a Trindade está presente no templo da comunhão matrimonial. Assim como Deus habita nos louvores do seu povo (S1 22/21,4), assim também vive intimamente no amor conjugal que lhe dá glória" (n. 314). Além disso, como nos ensina João, somente se nos amarmos uns aos outros, Deus permanece em nós, e seu amor em nós é plenamente realizado (1 Jo 4,12). "Por isso, aqueles que têm desejos espirituais profundos não devem sentir que a família os 
afaste do crescimento na vida no Espírito, mas é um percurso de que o Senhor se serve para os levar às alturas da união mística" (n. 316).

Recomendando a oração em família, especialmente a participação dominical na Eucaristia, o Papa cita Ap 3,20, a cena em que o Cristo bate à porta, esperando ser convidado para a ceia. Lembra também a palavra de Jesus sobre o cálice, na instituição da Eucaristia, o cálice da "nova aliança" (Lc 22,20), aliança apresentada como um matrimônio desde Oseias (Os 2,4-25), culminando no Novo Testamento com a união entre Cristo e a Igreja (Ef 5,25 e 31-32; Ap 19,7 e 21,2). Quanto à "espiritualidade do amor exclusivo e libertador", que é a pertença completa a uma única pessoa, Francisco lembra que não pode ser "apenas uma lei vivida com resignação". É "uma pertença do coração, lá onde só Deus vê" (n. 319). Nesta altura, o texto cita Mt 5,28, o que me parece equivocado. Não será Mt 6,4b.6b.18b, onde Jesus fala do Pai que vê no escondido? ${ }^{29}$ Mais adiante, a proximidade do cônjuge, um para o outro, é para ambos "sinal e instrumento da proximidade do Senhor, que não nos deixa sós, conforme sua promessa em Mt 28,20: Estou convosco todos os dias, até o fim dos tempos (n. 319).

“Toda a vida da família é um 'pastoreio' misericordioso", diz Francisco (n. 322). E continua: "Cada um, cuidadosamente, desenha e escreve na vida do outro", como os coríntios eram a "carta" escrita por Paulo, não com tinta, mas com o Espírito do Deus vivo (2Cor 3,2-3). Cada um é um pescador de gente (Lc 5,10) que, em nome de Jesus, lança as redes $(\operatorname{Lc} 5,5)$ para os outros, ou um lavrador que trabalha nessa terra boa que são os seus entes queridos [...], pois foi Deus quem neles semeou muitas coisas boas (cf. Mt 13,3-9), com a esperança de que as façamos crescer" (n. 322).

Quanto à atenção de uns para com os outros, na família, Francisco lembra as atitudes de Jesus, p. ex. fitando com amor o jovem que veio pedir-lhe orientação, em Mc 10,21, ou perguntando a Bartimeu: Que queres que eu te faça? (Mc 10,51) Entretanto, "o núcleo familiar não só acolhe a vida gerando-a em seu próprio seio, mas abre-se também, sai de si para derramar o seu bem nos outros [...], especialmente pela hospitalidade" (n. 323-324), como o recomenda a carta aos hebreus: Não descuideis da hospitalidade... (Hb 13,2).

29 "no escondido" (BJ), ou "em secreto" (Almeida),"no segredo" (TEB), gr. en tô kryptô. 
As últimas citações bíblicas aduzidas pelo Papa - Mt 22,30 e 1Cor 7,29-31 - poderiam surpreender-nos. A primeira, é a palavra de Jesus aos saduceus, sobre a vida futura: Na ressurreição, não haverá homens e mulheres casando-se... E a segunda, é a de Paulo, advertindo sobre a transitoriedade da vida: Irmãos, o tempo abreviou-se. Então, doravante, os que têm mulher vivam como se não tivessem mulher; os que choram, como se não chorassem... pois a figura deste mundo passa. Estas palavras, diz Francisco, "estão inseridas na dimensão última e definitiva de nossa existência, que precisamos recuperar. Assim, os esposos poderão reconhecer o sentido do caminho que estão percorrendo. [...] Nenhuma família é uma realidade perfeita, [...] mas requer um progressivo amadurecimento da sua capacidade de amar. [...] Todos somos chamados a manter viva a tensão para algo mais além de nós mesmos e dos nossos limites, e cada família deve viver neste estímulo constante. [...] Não percamos a esperança por causa dos nossos limites, mas também não renunciemos à procura da plenitude de amor e comunhão que nos foi prometida" (n. 325).

\section{As citações implícitas}

São também importantes. Como a que encontramos na já famosa nota 351 da Exortação, na qual, falando da possível "ajuda dos sacramentos", Francisco adverte, citando a Evangelii Gaudium, que "o confessionário não deve ser uma câmara de tortura..." (EG, n. 44) e que "a Eucaristia não é um prêmio para os perfeitos..." (EG, n. 47) ${ }^{30}$. É evidente que, em ambos os casos, especialmente no caso da Eucaristia, a citação bíblica implícita é a que se encontra nos três Sinóticos ${ }^{31}$, na resposta que Jesus dá aos fariseus e/ou a seus escribas, que censuravam aos discípulos o fato de "seu Mestre comer com os publicanos e os pecadores". Segundo Mateus, é a seguinte a resposta de Jesus: Não são os que têm saúde que precisam de médico, mas sim os doentes. Ide, pois, e aprendei o que significa: Misericórdia é que eu quero, e não sacrifício ritual $^{32}$. Com efeito, não vim chamar justos, mas pecadores (Mt 9,13). Quer dizer: a consciente atitude de Jesus, "misturando-se" com os "pe-

30 Na nota 51 da Evangelii Gaudium, comentando a afirmação de que "a Eucaristia não é prêmio", em vez de uma justificação bíblica, Francisco prefere citar dois sucintos textos de AMBRÓSIO e um, mais extenso, de CIRILO DE ALEXANDRIA.

31 Mc 2,17; Mt 9,13; Lc 5,32.

32 Tradução interpretativa do termo original hebr. zebah, que não é simplesmente "sacrifício", mas sacrifício "ritual", concretamente, a degola de animais. 
cadores", é biblicamente justificada pelo extraordinário texto de Oseias 6,6 que, pelo jeito, os fariseus ainda não tinham aprendido. Não é preciso dizer que este "Ano da Misericórdia" é mais um estímulo de Francisco para enfim aprendermos, todos nós, de verdade, "o que significa" a Misericórdia que Deus quer ${ }^{33}$. É evidente, portanto, que, mesmo sem tê-los citado explicitamente, Francisco, na nota mencionada, implicitamente cita, com Mateus, também Oseias.

\section{Conclusão}

Vê-se que a fundamentação bíblica da Exortação é sólida, otimista, positiva, inspiradora. Ela nos ajuda, sim, como se propõe Francisco na Introdução, a "aprofundar, com liberdade, algumas questões doutrinais, morais, espirituais e pastorais" (n. 2), referentes ao matrimônio e à família. Entretanto, exatamente por não pretender nem poder tratar de tudo, a abrangência bíblica do documento, apesar de relativamente longo, é limitada. Assim, o Papa evita - e não era o caso de fazê-lo - entrar em detalhes exegéticos discutidos, p. ex. a chamada "cláusula mateana" ${ }^{34}$. Seu objetivo, porém, reafirmado ao longo de toda a Exortação, é contribuir para que "o anúncio cristão que diz respeito à família seja, deveras, uma boa notícia" (cf. n. 1). Espero que a análise feita neste artigo tenha conseguido demonstrar que o objetivo foi plenamente alcançado.

\section{E-mail do autor:}

ney.brasil@itesc.org.br

33 Cf. PEREIRA, Ney Brasil, "Misericórdia, bondade, amor. A misericórdia que Deus quer", em "Encontros Teológicos", revista da FACASC, Florianópolis, n. 71 (2015/2), pp. 125-138; também em REB, Petrópolis, número 301, jan./mar. 2016, pp. 199-210.

34 Mt 5,32 e 19,9 (diferente de Mc e Lc) : "a não ser em caso de porneia, lit. no gr. "prostituição", não "adultério", que no gr.é moicheia, mas há toda a problemática do substrato hebr. zenût, suposto em At 15,20. 